\title{
MEDICAL GRADING OF THE INDUSTRIAL WORKER
}

BY

\author{
J. P. ELIAS * \\ Llandudno
}

Towards the middle of 1943 the problem of supplying workers to replace the labour turn-over in a large Royal Ordnance Filling Factory became more acute through the transfer of a large number of the younger male and female workers to the forces and to other industries. Local recruitment on a large scale was necessary and in the fourth year of total war unemployed persons in an industrial area were inevitably for the most part physically substandard or aged. The level of production of filled ammunition had to be maintained and this could only be done if full use was made of the maximum productive capacity of each individual. At a meeting of senior production and labour management staffs, instructors of the Training School and the medical officers, it was agfeed that the work carried out in the factory fell within five grades, and the medical department was asked to determine at the time of the entrant's examination which grade of work could be most efficiently performed by the applicant. The agreed grades of work were as follows:

(1) Heavy general labouring.

(2) Rough assembly, i.e. unskilled work involving the handling of stores not exceeding $25 \mathrm{lb}$. in weight.

(3) Machine operating.

(4) Semi-skilled assembly.

(5) Skilled assembly.

It was decided to limit initially the entry of graded labour to 800 men into one section of the factory, a section in which there was a demand for all five grades of labour. The selective medical examination of entrants being wholly the responsibility of the medical department, it was necessary to organize in detail a routine of examination that, in view of the large influx of new labour that was expected, would not consume too much of the time of the medical officers who had numerous other functions to carry out in the factory. All jobs carried out in the section were carefully reviewed and particular note made of a few specific jobs falling within the definition of each grade. Examples of these jobs are:

Grade 1. Loading railway trucks in transit sheds.

Grade 2. Unpacking and cleaning empty 4.2inch trench mortar bombs.

\footnotetext{
* Previously Senior Medical Officer, Royal Ordnance Factory, Ministry of Supply, Bridgend.
}

Grade 3. Operating presses.

Grade 4. Wiring cartridges between the fins on the tail-piece of trench mortar bombs.

Grade 5. Assembling ignition devices.

\section{Psychological Tests}

It was obvious that it would be necessary to take into consideration personal qualities as well as physical fitness in selection of workers for these different grades of work; the machine operator required a degree of performance intelligence, the semi-skilled assembler required dexterity, and the skilled assembler required both dexterity and performance intelligence. In order to assess these qualities quickly and with some accuracy during the medical examination of large numbers of men, two psychological tests were incorporated in the scheme of examination, namely the Peg-in Board for dexterity and Cube Imitation for performance intelligence. Before deciding to make use of these two particular tests they were tried out on some of the women who were to be replaced by the new-coming men. A few good, average and indifferent workers were selected by the shop manager for testing. The speed which each worker was assigned on her test score, when correlated with the category to which the supervisory staff had assigned her as a result of her work record, assured the managerial staff of the value of grading. At the same time it gave us standards for allocating new entrants to grades requiring performance intelligence or dexterity. It was found that the good worker inserted 76 pegs into the board in 2 minutes and scored 7 at cube imitation test before breaking down, the average worker scored 65 and 5 and the indifferent worker 55 and 3 respectively.

\section{Methods and Grading}

To expedite and standardize examination the form shown in fig. 1 was devised, and this form accompanied the applicant in a planned circuit of the surgery. The first portion of the form was completed by clerks and nurses in various rooms with the help of a male orderly to collect urine specimens. The second portion was completed by a medical officer in a consulting room and the applicant then moved to another room to be assessed by a second medical officer. This assess- 


\begin{tabular}{l} 
BRIDGEND FORM 329 \\
Name \\
Address \\
Age \\
History \\
Sight R. L. J. \\
Urine \\
B.P. over 50 \\
\hline Heart \\
Lungs \\
Skin \\
Abdominal Wall \\
Varicose veins \\
Muscular control . \\
Physique
\end{tabular}

Peg Insertion

Cube Imitation

Fit for Factory?

Fit for Contact?

Grade

$$
\text { FIG.-1 }
$$

ment was based on the recorded findings, but if necessary, re-examination directed to any doubtful feature assured a sound assessment of fitness to work in the factory and fitness to work in contact.* Finally, the accepted applicant was graded into his best work category.

Sometimes the medical officer was able to grade from the findings of the physical examination alone; for instance, a man's poor standard of vision or some limitation of function of a hand might be such that it was obvious that he would be unable to carry out work requiring the quality of dexterity, and he would be placed in Grade 1 or Grade 2 according to his physical capacity. But in the majority of cases the assessing medical officer required knowledge of his intelligence and dexterity, and the man was passed to an adjacent room, where the two selected tests were carried out by clerks who quickly became proficient after a little instruction. The scores were entered on the third portion of the form and the applicant returned for grading by the medical officer from the integrated record of the man's physical capacity and essential abilities.

Grading examinations were carried out on three days a week at the rate of 100 men a day and it was found that 20 men could be dealt with in an

* Fitness for contact implies, in a Royal Ordnance Filling Factory, fitness to work in contact with TNT, tetryl, fulminate of mercury and lead azide. hour provided the doctor carrying out the physical examination was periodically relieved.

The psychological tests were readily accepted and a negativistic attitude towards the test situation was very rare indeed. It was soon apparent that the trial standard scores in the dexterity test of the average woman worker could be reached by a good proportion of those tested, but the score of the good woman worker (76 pegs in 2 minutes) was rarely reached and the score of 70 was accepted as the criterion of dexterity for placement in Grades 4 or 5. On the other hand, the distribution of scores in performance intelligence tests corresponded more closely to that of the women taken as standards and a score of 7 or upwards in the cube imitation test was required for placement in Grades 3 or 5.

The grade of each man who entered the factory was transmitted through the Labour Department to the Training School. Here the new entrant was tried out on various jobs and trained to perform those to which he showed most aptitude. The Chief Instructor of the Training School reported that the correlation between performance and medical grading was good, but we agreed that correlation diminishes with advancing age when patterns of movement are less readily acquired. The tests of abilities were necessarily superficial, for time was the over-riding factor when large numbers of men were urgently required for war production. The applicants were submitted from numerous Labour Exchanges scattered over a radius of 25 miles from the factory, the main industry of the area being coal-mining and some heavy metal industry.

As a total of 10,312 men were medically graded we had a valuable assessment of the quality of labour which was available in the country in the fourth and fifth years of total war. The data have been analysed from the point of view of industrial capacity in Table 1 and from the point of view of personal incapacity in Table 2.

Periodically a number of applicants who were passed fit for non-contact work only were not graded because at the time of their examination non-contact work was not available in the factory. The category of temporarily unfit has been confined to those who did not present themselves for reexamination. A large number who were regarded as temporarily unfit at the first examination were re-examined later and were included in their appropriate category when the temporary disability had been rectified.

\section{Defects}

Analysis of individual defects found by medical examination of 10,389 workers is given in Table 2.

Vision was regarded as defective if acuity was less than Snellen 6/18 with the aid of glasses if they are worn, and for Grade 5 (skilled assembly) near vision up to J2 was required. Visual defects were frequent in all age groups. Monoculars were at first totally rejected on account of the risk attached 
TABLE 1

ASSESSMENT OF INDUSTRIAL CAPACITY IN A GROUP OF 10,312 WORKERS

\begin{tabular}{|c|c|c|c|c|c|c|c|c|c|c|c|c|c|c|c|}
\hline \multirow{2}{*}{$\begin{array}{c}\text { Age } \\
\text { group }\end{array}$} & \multirow{2}{*}{$\begin{array}{l}\text { No.ex- } \\
\text { amined }\end{array}$} & \multicolumn{6}{|c|}{$\begin{array}{l}\text { Fit for contact } \\
\text { Grades: } \\
\text { Percentage of total graded }\end{array}$} & \multicolumn{6}{|c|}{$\begin{array}{l}\text { Fit for non-contact } \\
\text { Grades: } \\
\text { Percentage of total graded }\end{array}$} & \multirow{2}{*}{$\begin{array}{l}\text { Temp. } \\
\text { unfit }\end{array}$} & \multirow[t]{2}{*}{ Unfit } \\
\hline & & Total & 1 & 2 & 3 & 4 & 5 & Total & 1 & 2 & 3 & 4 & 5 & & \\
\hline $\begin{array}{c}18-29 \\
30-39 \\
40-49 \\
50-59 \\
60 \text { and } \\
\text { over }\end{array}$ & $\begin{array}{l}1782 \\
2011 \\
2256 \\
2444\end{array}$ & $\begin{array}{l}1052 \\
1250 \\
1249 \\
1253\end{array}$ & $\begin{array}{r}12 \cdot 07 \\
13 \cdot 76 \\
7 \cdot 45 \\
3 \cdot 11 \\
\\
\text { nil }\end{array}$ & $\begin{array}{l}15 \cdot 02 \\
20 \cdot 88 \\
28 \cdot 82 \\
47 \cdot 96 \\
\\
64 \cdot 25\end{array}$ & $\begin{array}{r}14.92 \\
16 \cdot 72 \\
18 \cdot 11 \\
16 \cdot 44 \\
\\
8.89\end{array}$ & $\begin{array}{l}25 \cdot 66 \\
21 \cdot 12 \\
19 \cdot 77 \\
16 \cdot 68\end{array}$ & $\begin{array}{c}31 \cdot 36 \\
27 \cdot 52 \\
28 \cdot 85 \\
15 \cdot 8 \\
\\
7 \cdot 68\end{array}$ & $\begin{array}{l}373 \\
397 \\
539 \\
471\end{array}$ & $\begin{array}{c}34 \cdot 58 \\
6 \cdot 3 \\
2 \cdot 66 \\
9 \cdot 24 \\
\\
\text { nil }\end{array}$ & $\begin{array}{l}28 \cdot 42 \\
32 \cdot 74 \\
58 \cdot 21 \\
66 \cdot 99\end{array}$ & $\begin{array}{c}5 \cdot 89 \\
26 \cdot 95 \\
8 \cdot 1 \\
4 \cdot 95 \\
\\
4 \cdot 75\end{array}$ & $\begin{array}{l}15 \cdot 55 \\
26 \cdot 95 \\
17 \cdot 31 \\
10 \cdot 23 \\
11 \cdot 86\end{array}$ & $\begin{array}{c}15 \cdot 55 \\
7 \cdot 1 \\
13 \cdot 73 \\
8 \cdot 58\end{array}$ & $\begin{array}{r}50 \\
44 \\
69 \\
128\end{array}$ & $\begin{array}{l}307 \\
320 \\
399 \\
592\end{array}$ \\
\hline Totals & 10312 & 5455 & & & & & & 2180 & & & & & & 343 & 2334 \\
\hline
\end{tabular}

TABLE 2

ASSESSMENT OF PERSONAL CAPACITY IN A GROUP OF 10,389 WORKERS EXAMINED Key: $A=$ fit contact; $B=$ fit non-contact; $C=$ unfit.

\begin{tabular}{|c|c|c|c|c|c|c|c|c|c|c|c|c|c|c|c|c|c|c|}
\hline \multirow{2}{*}{\multicolumn{4}{|c|}{ Disability }} & \multicolumn{3}{|c|}{$\begin{array}{c}\text { Age group: } \\
18-29 \\
\text { Number } \\
\text { examined: } \\
1794\end{array}$} & \multicolumn{3}{|c|}{$\begin{array}{c}\text { Age group: } \\
30-39 \\
\text { Number } \\
\text { examined: } \\
2011\end{array}$} & \multicolumn{3}{|c|}{$\begin{array}{c}\text { Age group: } \\
40-49 \\
\text { Number } \\
\text { examined: } \\
2285\end{array}$} & \multicolumn{3}{|c|}{$\begin{array}{c}\text { Age group: } \\
50-59 \\
\text { Number } \\
\text { examined: } \\
2469\end{array}$} & \multicolumn{3}{|c|}{$\begin{array}{c}\text { Age group: } \\
60 \text { and over } \\
\text { Number } \\
\text { examined: } \\
1830\end{array}$} \\
\hline & & & & A & B & $\mathrm{C}$ & A & B & $\mathrm{C}$ & A & B & $\mathrm{C}$ & A & B & C & $\mathbf{A}$ & B & $\mathrm{C}$ \\
\hline \multicolumn{4}{|c|}{ Defective vision (including mono- } & 24 & 17 & 67 & 6 & 8 & 42 & 54 & 20 & 77 & 106 & 31 & 146 & 96 & 41 & 175 \\
\hline Illiteracy $\quad \ldots$ & $\ddot{\cdots}$ & $\because$ & $\because$ & 8 & 9 & 25 & - & - & 13 & 10 & 8 & 12 & $\begin{array}{r}100 \\
9\end{array}$ & 9 & $\begin{array}{r}140 \\
26\end{array}$ & $\begin{array}{r}90 \\
6\end{array}$ & $\begin{array}{r}41 \\
5\end{array}$ & 21 \\
\hline \multicolumn{19}{|l|}{ Renal- } \\
\hline Albuminuria & .. & $\ldots$ & . & 2 & 12 & 15 & 1 & - & 16 & 3 & 7 & 15 & 10 & 6 & 26 & 6 & 6 & 24 \\
\hline Glycosuria & . & . & . & 6 & 一 & 4 & - & 2 & 7 & 25 & 1 & 8 & 27 & 3 & 5 & 14 & 4 & 16 \\
\hline Nephritis .. & . & - & . & -2 & 1 & 2 & - & 1 & 一 & - & - & 1 & - & - & - & - & - & $\overline{5}$ \\
\hline Other renal & & .. & .. & 3 & 1 & 2 & - & - & - & - & - & 1 & 1 & 1 & $\overline{00}$ & $\overline{21}$ & $\overline{1}$ & 5 \\
\hline Hyperpiesis (BP. 18 & $80+)$ & . & .. & 1 & - & - & - & - & 1 & 2 & - & 1 & 13 & 1 & 23 & 24 & 15 & 73 \\
\hline Heart Lesions & . & . & . & 66 & 17 & 17 & 18 & 6 & 22 & 30 & 4 & 22 & 42 & 8 & 30 & 26 & 13 & 101 \\
\hline Tachycardia & $\cdots$ & $\cdots$ & $\cdots$ & 107 & 14 & 15 & 88 & 22 & 15 & 76 & 6 & 3 & 42 & 5 & 47 & 15 & 8 & 22 \\
\hline \multicolumn{4}{|c|}{$\begin{array}{l}\text { Lung lesions- } \\
\text { Silicosis or pneumoconiosis }\end{array}$} & - & 24 & 2 & - & 106 & 18 & - & 80 & 36 & - & 56 & 40 & - & 11 & 22 \\
\hline Reticulation & .. & .. & . & 10 & 13 & 3 & 5 & 3 & 10 & $\overline{11}$ & 10 & 1 & 6 & 3 & 11 & 1 & 1 & 4 \\
\hline T.B. ... . & .. & .. & .. & 2 & 8 & 10 & - & 1 & 9 & - & - & 6 & - & 1 & 2 & - & - & 1 \\
\hline Bronchitis & .. & .. & $\ldots$ & 16 & 29 & 10 & 8 & 27 & 18 & 27 & 34 & 26 & 29 & 44 & 54 & 5 & 23 & 49 \\
\hline Other lesions & .. & . & .. & 14 & 28 & 25 & 4 & 9 & 16 & 19 & 23 & 23 & 14 & 18 & 10 & 6 & 10 & 21 \\
\hline Skin lesions . . & . & . & . & 19 & 35 & 17 & 5 & 26 & 11 & 13 & 17 & 26 & 14 & 18 & 17 & 4 & 18 & 21 \\
\hline \multicolumn{19}{|c|}{ Gastric disorders- } \\
\hline Ulceration & . & . & . & $\overline{10}$ & 9 & 5 & 8 & 54 & 15 & 1 & $\overline{10}$ & $\overline{16}$ & $\overline{17}$ & 2 & $\begin{array}{l}9 \\
0\end{array}$ & $\overline{1}$ & $\overline{3}$ & 1 \\
\hline Other disorders & $\cdots$ & . & $\cdots$ & 18 & 28 & 6 & - & - & 6 & 11 & 18 & 16. & 17 & 6 & 8 & 1 & 3 & 6 \\
\hline Neurosis $\quad$. & . & . & .. & 35 & 11 & 32 & 9 & 5 & 26 & 11 & 2 & $13^{\circ}$ & 8 & 2 & 16 & 1 & 一 & 8 \\
\hline Nỵstagmus $\because$ & . & . & .. & 6 & - & 8 & 6 & 5 & 13 & 18 & 7 & 19 & 21 & 2 & 26 & 3 & 1 & 12 \\
\hline Disease of C.N.S. & .. & . & . & 3 & 2 & 3 & - & - & 4 & 1 & 2 & 8 & 3 & 2 & 7 & 3 & 3 & 10 \\
\hline Epilepsy $\quad$.. & . & .. & . & - & - & 1 & - & - & 1 & 一 & - & - & - & - & 1 & - & - & 1 \\
\hline \multirow{2}{*}{\multicolumn{19}{|c|}{$\begin{array}{l}\text { Hernia- } \\
\text { Inguinal and femural- }\end{array}$}} \\
\hline & & & & & & & & & & & & & & & & & & \\
\hline Without truss & $\therefore$ & $\therefore$ & .. & - & - & - & 1 & - & 7 & 7 & 2 & 10 & 4 & 3 & 23 & 8 & 3 & 39 \\
\hline Ventral $\quad$. & & & .. & - & - & - & - & - & 3 & 2 & 1 & 3 & 2 & - & 1 & 5 & 2 & 4 \\
\hline Rheumatism and a & Irthriti & & & 25 & 2 & 2 & 9 & - & 6 & 30 & 4 & 9 & 20 & 5 & 5 & 9 & 3 & 6 \\
\hline \multicolumn{4}{|c|}{ Physical deformity (including bone } & & & & & & & & & & & & & & & \\
\hline injury) ～.. & & & & 90 & 16 & 32 & 38 & 13 & 31 & 69 & 8 & 52 & 71 & 12 & 52 & 27 & 10 & 42 \\
\hline
\end{tabular}


to work in explosives, but later they were accepted for work in the less dangerous jobs.

The number of illiterates in the lower age groups was higher than expected though the majority of them scored average or better in the performance intelligence test.

Albuminuria was regarded as a bar to contact work unless there was good reason to believe the renal function was undamaged; symptomless glycosuria was not regarded as a bar to contact work.

The blood pressure of applicants aged 55 years and upwards was taken as a routine, under that age only at the request of the examining medical officer. Tachycardia was recorded when no physical signs of cardiac disease were found and its significance was assessed by the medical officer responsible for grading.

Silicosis or pneumoconiosis was recorded from the declaration of compensated injury or disease in the past which is signed by every applicant, while under the heading "reticulation" were placed the cases of "dust on lung" which had been turned down by the Silicosis or Pneumoconiosis Board. Cases of reticulation without physical signs of bronchitis were accepted for contact work and were able to perform this work without difficulty, but certified silicosis and pneumoconiosis were barred from contact work. The early stage and even moderately advanced silicotic was usually able to work comfortably in non-contact powder filling shops, but those who readily developed dyspnoea or were in the advanced stages were quite unfit for a filling factory.

Most skin lesions are a bar to contact work though acne vulgaris and pigmentation changes do not apparently increase susceptibility to dermatitis from contact powders.

Neurosis was mostly recorded from the history, and the degree of mental discomfort (important in a factory handling explosive) was assessed by a medical officer who had some experience of psychiatry.

Nystagmus was a cause of rejection until symptoms had disappeared.

Hernias were rejected until they were provided with a suitable truss.

\section{Summary}

The value of medical selection and medical grading has been checked by reference to subsequent labour turn-over and to production output. During a period of 15 months, from an intake of 6072 men, 141 were discharged on medical grounds, and no loss of production followed the replacement of experienced workers on a large scale by new but graded labour.

\section{Acknowledgment}

My thanks are due to Dr. A. J. Amor, Chief Medical Officer, Ministry of Supply, for his guidance in the presentation of this report, to Mr. L. J. Corbett, Superintendent, R.O.F., Bridgend, for permission to publish these findings, and to the medical, nursing and clerical staff for their help in the work. 